\title{
The development of online marketing channel for safe vegetable in Thailand
}

\author{
Kanokpatch Koprasert ${ }^{1}$, Nittaya Ngamyingyong ${ }^{2}$, Jemine Settheerathan ${ }^{3}$ \\ 1,2,3 Nakhon Pathom Rajabhat University \\ ${ }^{1}$ koprasert.kanokpatch@gmail.com, ${ }^{2}$ jnittaya2109@gmail.com, ${ }^{3}$ jemine.settheerathan@gmail.com
}

\begin{abstract}
This research aims were to; 1) to develop an online marketing channel for safe vegetable in Thailand. The research model was mixed methods. The theory of Extended Model of Internet Commerce Adoption (eMICA) was used as a research framework. The research area was Nakhon Pathom Province. The sample group was divided into 3 groups as follows; 1) 30 smart farmers who grow safe vegetables; 2) People who are involved in the safe vegetable business, including entrepreneurs and academics, were 10 people by using a specific randomization and 3) 400 people of online consumers by using simple randomization. The tools used were semi-structured interviews and questionnaires. Then analyze the results for the development of online marketing channels. The research found that farmers had online marketing channels sorted by their sales as follows; Facebook 16 users, Instagram 5 users, online orders 7 users and Shopee 2 users. The results of the trial are sold through online marketing channels, when comparing the highest efficiency was Facebook channel where customers can reach at $78.23 \%$ and generate the most income at 68.15 percent. Research findings on shipping, packaging, and consumer behavior are emerging in the process of developing online marketing channels
\end{abstract}

Keywords

online marketing channel, safe vegetable

Article Received: 10 August 2020, Revised: 25 October 2020, Accepted: 18 November 2020

\section{Introduction}

Thailand is the 11th food exporter in the world and the 2nd in Asia. Export value of US\$33,100 million (Office of the National Economic and Social Development Council, 2019). It creates jobs for more than 11 million people in rural areas (National Statistical Office, 2019). Agricultural income accounts for 8.5 percent of GDP in Thailand (Office of the National Economic and Social Development Board; NESDB, 2019). In 2019, vegetables generated US\$ 2,996 million in revenue for the country (Office of the Permanent Secretary, Ministry of Commerce, 2019). Nakhon Pathom Province is the main area for growing vegetables with a total area of 709,474 rai and the number of farmers 48,639 households (Nakhon Pathom Provincial Agriculture Office, 2019). According to a review of the vegetable supply chain literature in Thailand, it was found that there was a lack of readiness in the production process with high production costs, uneven output, unstable selling prices, and the middleman has high pricing power. Including the complexity of marketing channels and narrow marketing channels. The characteristics of the product perishable and the shelf life is short. This makes it necessary for packaging that is able to maintain quality and suitable transportation in order to reliably meet customer needs in terms of quality, quantity and price (Donald \& David, 1996; Huang et al, 2008). In addition, the current changes in the purchasing behaviour of customers who are more popular to buy products via online channels and the development of Thailand needs to be driven by innovation. There has been a shift from traditional agriculture to modern agriculture with an emphasis on management and technology. Farmers must be able to be modern entrepreneurs by implementing technology in the management process, sharing information, and optimising resource allocation using the online trading system (Xiuhui \& Qinan, 2007). Online marketing channels are low-cost, time-consuming and cost-effective marketing tools. It provides opportunities for farmers who want to develop their business processes and create their image up to date by adopting appropriate technology. This research is the development of online marketing channels for safe vegetables in Thailand to increase the potential of the safe vegetable supply chain in 4 areas; 1) reduce costs, 2) increase production quality and product standards, 3) increase various marketing channels, and 4) manage and transmit information, knowledge and information, technology applications. The objective of this research is to develop an online marketing channel for safe vegetables in Thailand. The expected benefits of this research are to provide farmers with a sustainable competitive advantage, generate more income, and become self-reliant by using information technology. This resulted in a prototype online marketing channel that could be applied to conventional agricultural products, leading to a real development in $21 \mathrm{st}$ century agriculture.

\section{Procedure For Paper Submission}

\section{A. Review stage}

Defining the meaning of online marketing as the use of information technology as a communication tool to support the implementation of business processes (Burgess et al, 2001). The adoption of digital technology and social media to provide information, receive online orders, and perform online transactions are business processes through information technology. Based on previous research reviews, it was found that The Theory of Extended Model of Internet Commerce Adoption: eMICA, Burgess et al (2001) used in the development of commercial online marketing 
models consisted of 3 steps; 1) Implementing information technology and digital social media for the promotion of business products and services, 2) Implementing information technology and digital social media to provide information, news and services, and 3) Introduction of information technology and digital Social media is used for transaction processing. Increasing the functionality of information technology and digital social media is the application of innovation to add value to activities in the vegetable supply chain through information management and multitasking (Timmer, 1999). Including the implementation of online marketing models as a strategy to create competitive advantages, allowing customers to gain more value in the organisation's products or services than competitors for the survival and growth of the business organisation (Laudon, 2016). For entrepreneurs and farmers in Thailand, online marketing can be used to help increase business efficiency in 4 areas; 1) cost savings, 2) differentiation for products, and 3) building closer to customers. From past research studies on online marketing, it was found that the DeLone \& McLean Information System Success Model,(DeLone \& McLean,2003) which is a model theory used to measure the success of information systems by compiling various factors including quality. Information, quality of use systems, personal impact, and organisational impact. Researchers expanded the study by using Kotler's Theory of Purchasing Behaviour (2009) to describe the nature of consumer behaviour searching for questions about $6 \mathrm{Ws}$ and $1 \mathrm{H}$ which are; who is in the target market, what consumers buy, why do consumers buy, who is involved in consumer purchasing decisions, when do consumers buy, and how do consumers buy. Therefore, planning for the development of an effective marketing channel must be based on expected changes in consumer behaviour in the future, in line with previous research that consumers have a set price before making a purchase. When a consumer accepts a product price, it affects the acceptance of the quality of the product or service that the product or service is of suitable quality. Consumers will compare the quality of the product with the amount to pay that it is appropriate or not. If consumers think that it is appropriate, they will make a decision to buy the product. As for the success of online marketing channels such as websites, social media can be measured by retaining their customers by keeping them coming back for future purchases. Past research indicates that the quality of a website or social media will influence the decision to buy on a well-designed website or social media, causing more consumers to buy. In addition, in the process of developing the online market model, participation theory has been applied in the development by allowing those who are involved in the safe vegetable supply chain to share information and needs. In the same direction as previous studies, it was said that involving stakeholders such as users and service providers develop an online marketplace that will have an impact on the efficiency and responsiveness of their customers (Blanca Hernández, 2010; Kuan, Bock and Vathanophas, 2008; Julian Terry and Craig Standing, 2001) as shown in figure 1.

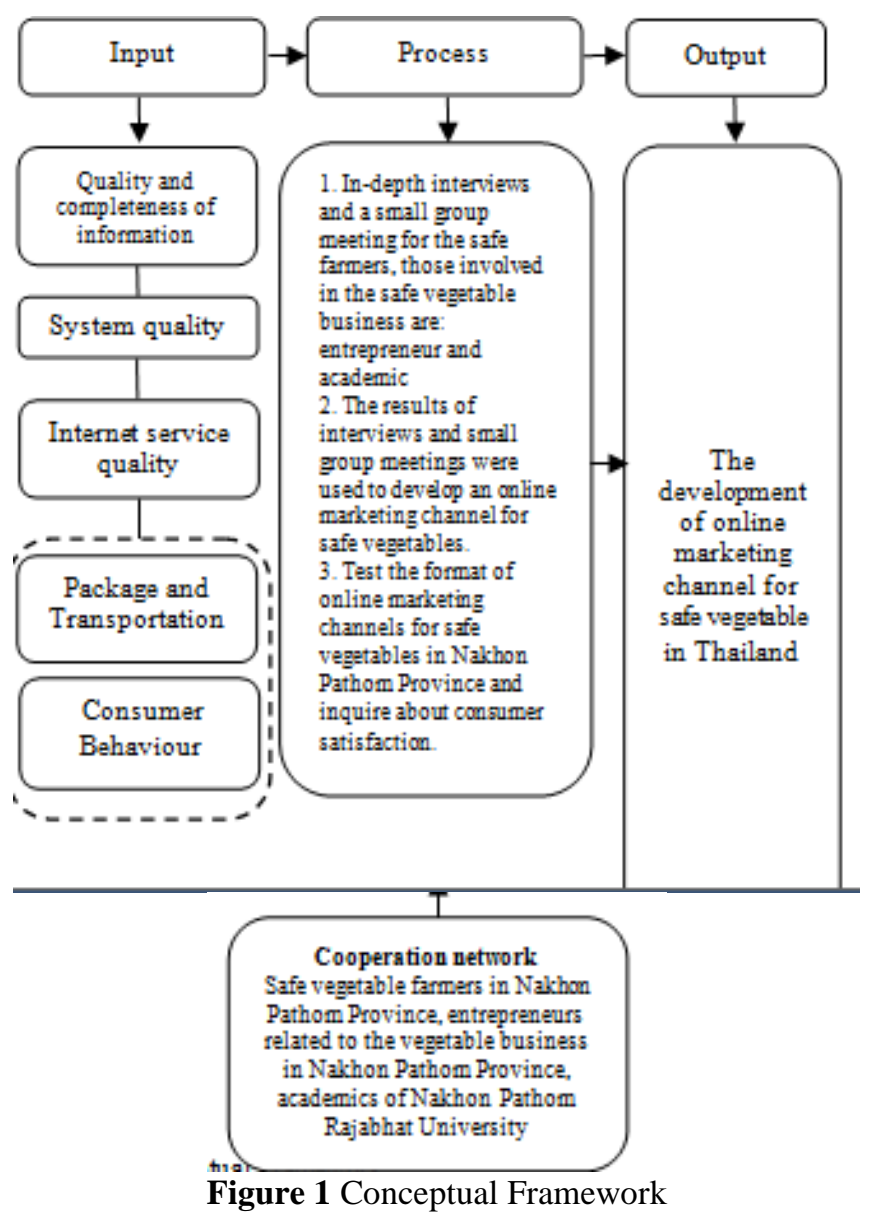

Source: Updated from Kuan, Bock and Vathanophas (2008).

\section{Materials And Methods}

This research is qualitative research. Areas in Nakhon Pathom Province. The qualitative research instrument was a structured interview. The data was examined using triangulation. The sample group consisted of 2 groups which are; 1) 30 safe vegetable farmers, 2) 10 government agencies and academics using a specific randomisation. Research method, this research uses a qualitative research methodology as the main guideline for the purpose of using information to develop online marketing channels for safe vegetable in Thailand. Researchers have reviewed the literature and past research documents, analysed and synthesized in order to obtain a research conceptual framework, to answer the research objectives with a total of 7 steps as follows;

Step 1 study document data, analyse basic data, which is a concept review. Explore past research papers and information from relevant websites to obtain criteria for selecting potential samples that use in the study, by collecting data from the original database of Nakhon Pathom agriculture and visiting the area to explore the potential and readiness of farmers in the area. Conduct analysis, assess potential to determine the case study area. Identify educational issues of selected areas, as well as to study conceptual documents, theories and research work related to the development of an online marketing channel for safe vegetable in Thailand.

Step 2 framing research from literature review and determine the sample group for data collection, by 
specifying the organic farming community enterprise and the safety agriculture group in Nakhon Pathom Province who have potential according to their relevance and knowledge in specific content.

Step 3 design research tools, to obtain the completeness of the content according to the research objectives. Researchers have defined tools, methods, and data collection methods, using in-depth interviews, brainstorming and engaging observations to develop an online marketing channel model for safe vegetable in Thailand.

Step 4 brainstorming activity, organised a workshop to allow farmers to discuss, exchange knowledge and experience in designing and developing online marketing channels for safe vegetables in Nakhon Pathom Province by using participatory action research. Establishing an innovative process and finding creative ideas from farmers to implement in developing an online marketing channel for safe vegetables in Thailand, by using participatory subgroup meetings. It was obtained by both farmers and researchers to provide feedback, a process for leading the development of online management and marketing. Resulting in creating added value and making the most of all sectors.

Step 5: design online marketing channel model and develop online marketing channel model for farmers to grow safe vegetable by synthesizing data from quality research, "The online marketing channel for safe vegetable in Thailand", and let experts evaluate the feasibility of the format.

Step 6: Testing to sell safety vegetable through online marketing channels and assessing the effectiveness of sales according to the research conceptual framework.

Step 7: collection of information to make it accurate and reliable. In which to examine the qualitative data, researchers will use the triangulation by using method as follows;

7.1 Data triangle investigation (Triangulation) is to prove that the information, researchers have obtained, correct or not by examining it from time and place and by people.

7.2 Comparisons based on multiple data collection methods (Methodological Traingulation) is the collection of information from various sources.

7.3. Comparisons from the use of multiple theories and concepts (Theory Triangulation), is the examination of whether the researcher can use theoretical concepts, analyses, and processes. This can be done by correlating the relationships in different terms based on facts, both cause and effect. The analysis will come out in a descriptive manner, leading to the answer in the study and summary (content analysis).

\section{Results And Discussion}

The development of the online marketing channel model for safe vegetable in Thailand shows the research results into 2 parts

1) Traditional safe vegetable marketing channel model

2) Online marketing channel model by application of eMICA format, the details are as follows;

1) Traditional safe vegetable marketing channel model
Traditional safe vegetable marketing channel model found that the marketing channel was complex. It goes through a number of intermediaries from the manufacturing process. Farmers must control the production process of safe vegetables that contain chemicals, do not exceed the standards set by the Ministry of Public Health. The produce must be safe for consumers through a process of midstream activities involved in the distribution of safe vegetable through multiple channels. For example, collectors that collect safe vegetable from farmers to deliver safe vegetables to the central market for exporting companies to foreign customers, hotels or restaurants, factories, shopping malls, retail stores, fresh markets or local markets to domestic customers. It can be seen that the traditional safe vegetable marketing channel has many stakeholders. It focuses on selling as buyers directly to the seller, known as offline sales. It is complicated by many steps. This reflects the increase in costs as the number of intermediaries passes and the longer the time, which results in deterioration of the quality of vegetables. From the above factors, the concept can be explained from Figure 2.

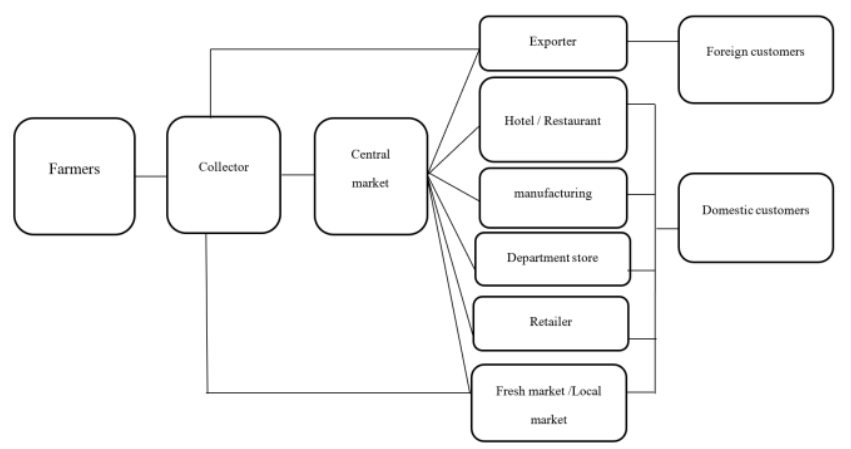

Figure 2 Traditional Safe Vegetable Marketing Channel Format

The change in the form of a new safe vegetable marketing channel by introducing information technology systems to help increase the marketing channels for farmers called online marketing channels, shortens the marketing funnel and reduces the number of intermediaries in the marketing funnel. It is direct sales from farmers, producers to consumers, which creates a competitive advantage. As it is a low cost marketing tool, it can reduce time and expenses as well as increase marketing channels. As a result, it creates business opportunities to reach buyers around the world, which is consistent with today's consumer behaviour using various online transactions. Therefore, it made the new safe vegetable marketing channel form a shorter channel. It can be delivered directly to consumers with logistics support activities in delivery and distribution. The concepts mentioned above can be explained from Figure 3.

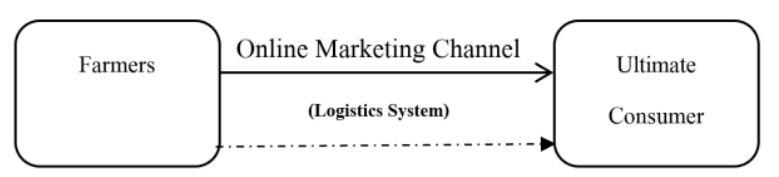

Figure 3 The new safe vegetable marketing channel model

2) Online marketing channel model by the application of eMICA format. 
Selling through online marketing channels is gaining popularity in the agricultural businesses that are needed in daily life such as fresh vegetables, safe vegetables, and organic vegetables. Farmers or entrepreneurs have added new marketing channels using IT and creativity, making it a different marketing channel model. As a result, they can trade online 24 hours a day and expand opportunities to people around the world. This will save costs, have the potential to increase sales, create a competitive advantage and provide two-way information. The application of the eMICA model in the development of an online marketing channel model for safe vegetable in Thailand was developed from the concept of Burgess et al (2011), by applying technology to the development of online marketing channels. There are 3 working steps which are;

Step 1: Inputs are a study of the needs of the buyer and the preparation of produce which is safe vegetables. In addition, farmers must prepare skills, knowledge of online marketing mix, new marketing elements that apply the traditional marketing component (4P), together with the technology talent that adds to the delivery of personalised service and privacy, resulting in a new marketing component, $6 \mathrm{P}+2 \mathrm{C}+$ 3S (Kalyanam \& Mclntyre, 2002, p 496) consisting of; 1) Product aspect, should be analysed to meet the needs of customers, 2) Price aspect, survey the purchasing behaviour on the internet, and found that price is not the main factor in choosing to buy. Entrepreneurs should focus on pricing to suit the quality of the product, 3) Distribution channels, creating a website or page on a social channel must have a domain that is easy to remember, easy to use and beautiful, including the convenience of ordering, 4) Marketing promotion, public relations and organising sales promotion activities, 5) Personalization service should focus on individualised services, collecting customer information, creating a different impression, and 6) Privacy, the operator must keep the customer's confidentiality and not distribute the customer's information before getting permission. 2C consists of; 1) Customer Service gives customers the importance to make repeat purchases, 2) Community online format used to communicate. $3 \mathrm{~S}$ consists of; 1) Efficient Site, easy website access, 2) Security, payment security and service usage, 3) Sale and promotion, which uses the above factors for promoting products and services of the business.

Step 2: Action by designing and testing online marketing channels with a focus on developing agricultural skills and knowledge. It is a potential enhancement in the form of "SMART Farmers Model" which is a guideline for applying digital innovation technology to develop farmers' potential to increase their competitiveness. It is also a systematic action model that helps proactively marketing to be effective and meet the highest consumer demand until repeat purchases. It consists of 5 elements:

1. Social Media (S) is a powerful marketing tool because there is a large number of individuals of all ages on social media. It represents a huge target audience. This research uses tools for business communication as well as promoting products and services to consumers via social media by tools such as Facebook, Instagram, and Line application. This group of tools will be used to target audiences because they can be used via smartphones, which are easily access, convenient, quick, economical, and can be done anywhere anytime. It can also present content including text, images and videos. Making it possible to run business with flexibility. It is also possible to create online networks between farmers with farmers, farmers with customers, and farmers with entrepreneurs. Also, it can be assistant agency or other relevant agencies to exchange information and knowledge and provide assistance to each other.

2. Marketing Tools \& Marketing Platform (M) Determining the right marketing tools by defining strategies that target the right target audience, adopting appropriate digital innovation technology tools for products and services, content formats and public relations channels through online marketing models, especially media preparation; such as video clips, photography, text formats and advertising content that are consistent with the consumer's reception behaviour. It also includes the selection of online marketing channels that are highly effective in selling and suitable for customers in Thailand such as shopee, order form online, Facebook, Instagram, Line, etc.

3. Assistants (A), government agencies and private sectors or educational institutions with expertise in digital technology and innovation, including online marketing, have become mentors to give advice and skills in various fields. For example; business smartphone training which requires learning of various functionalities, helping develop digital innovation for entrepreneurs, helping to start a group or create a network, marketing network, and commercial photography and video, etc.

4. Reviewer \& Influencer (R), recommending a product by a user of a product or service, or taking a picture of a customer by word of mouth, or presenting through social media is the most effective way of public relations. This will result in rapid and immediate dissemination of information such as only having customers or service recipients, or even business owners themselves can take pictures, shoot videos and share that information online. Even broadcasting via Face book live, it can communicate and distribute information about products and services to customers immediately. However, one of the important things to consider is to maintain the standard of products and services. This is to enable reviewers or photographers to present stories that have a positive impact on the business.

5. Technology Digital $(\mathrm{T})$, promoting the use of technology and digital innovations in business management such as computerised raw material management, the use of digital innovation technology as a medium for trading and exchanging products and services such as page creation, online marketing content, linking to the online marketplace platform, offering shop and product information, online trading, searching for new information and knowledge, etc. This will make running agribusiness online with convenience, help to reduce costs and expenses. Implementation of the aforementioned 5 elements, which are related and linked in a way of integration holistic. Providing support from assistant agencies to enable entrepreneurs to have the potential to operate their businesses effectively. The products obtained from the SMART Farmers Model can be used to formulate a strategic plan and an action plan to lead to clear concrete action. This will enable farmers to truly adopt digital innovation technology to enhance their business potential. 
Step 3: Product, using the form of online marketing channels, which include Facebook, Instagram, Line, Order form online, shopee to test sales of vegetables for processing work. It represents driving business systems in applying online marketing channels for safe vegetable by developing innovations to add value to activities in the vegetable supply chain. Through the management of information and a variety of functions, including a traceability process of online marketing channels to achieve optimisation. Correspond to the concept of Timmers (1999) says: online marketing is a technology that has the potential to effectively expand the market to consumers at low cost. It can explain the pattern for the development of online marketing channels for safe vegetable in Thailand, detailed in Figure 4. And show example of marketing channel such as Facebook, Instagram, line, shopee and online order from in Figure 5-9.

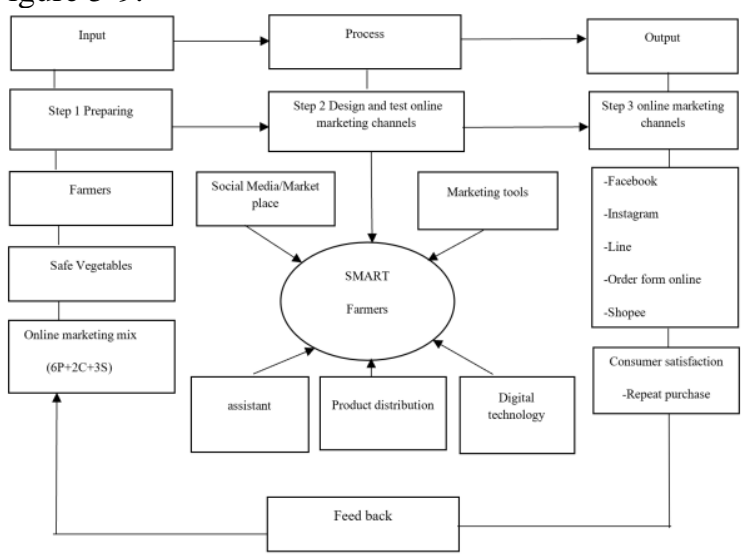

Figure 4 Format of online marketing channel by application of eMICA format
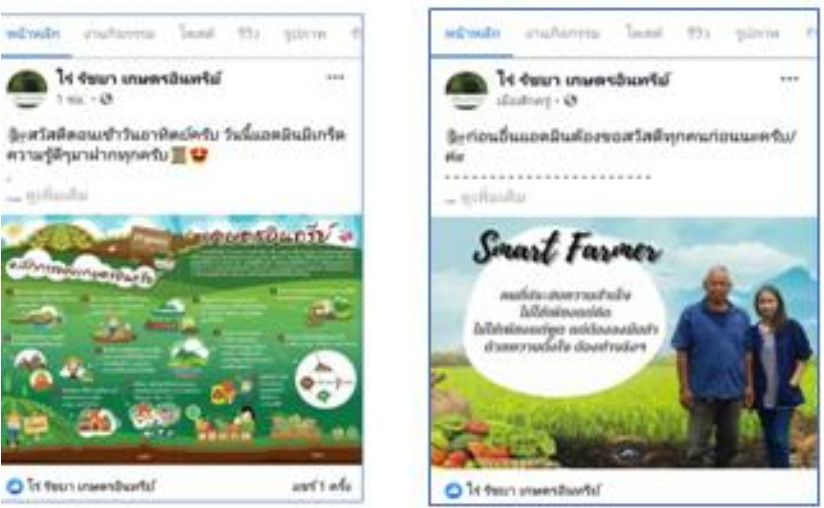

Figure 5 Example of marketing channels on Facebook
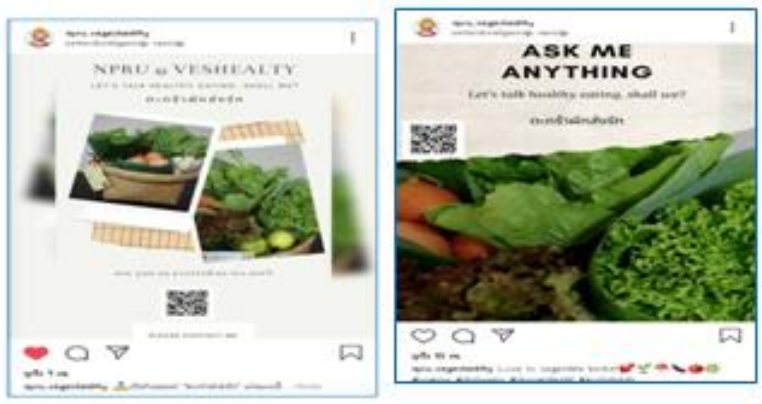

Figure 6 Example of marketing channels on Instagram

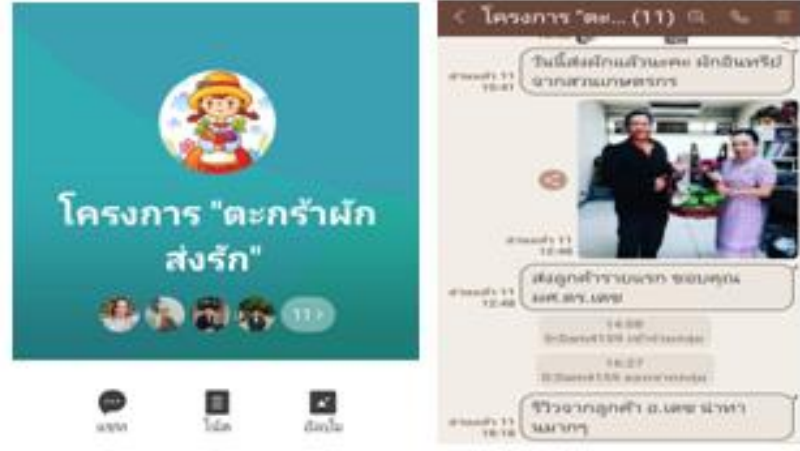

Figure 7 Example of marketing channels on line

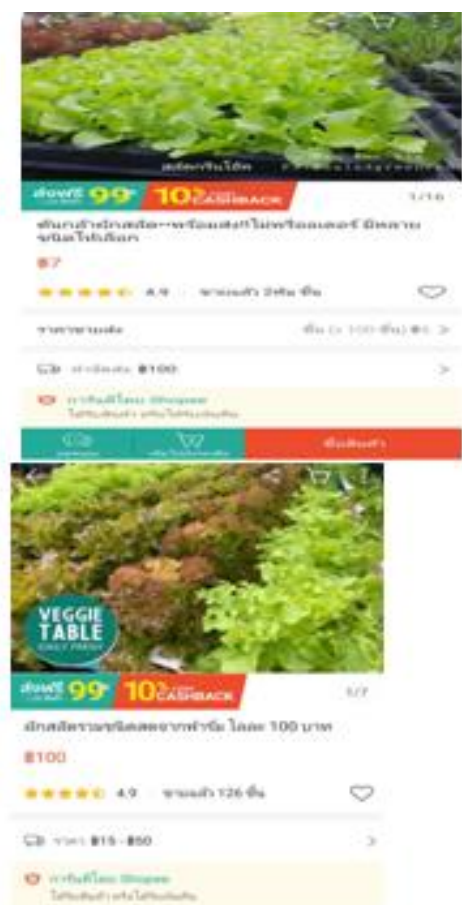

Figure 8 Example of marketing channels on shopee
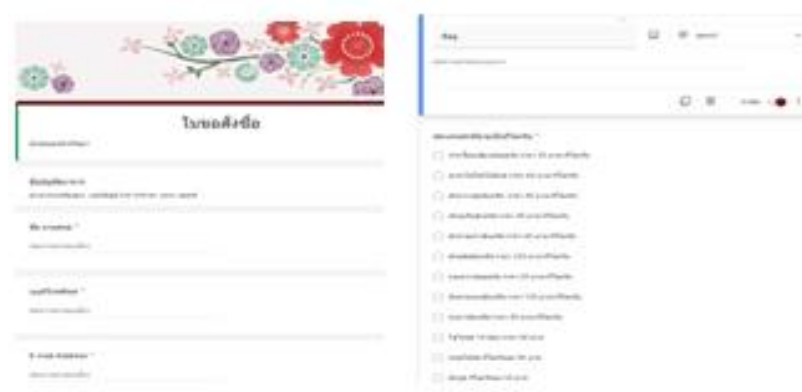

Figure 9 Example of marketing channels on online order from.

Online marketing channel efficiency for safe vegetable in Thailand

From the experiment of selling safe vegetable through online marketing channels in Thailand found that farmers had online marketing channels in order of sales: 16 Facebook users, 5 Instagram accounts, 7 online orders, and 2 Shopee users. This research by measuring the effectiveness of 3 aspects; 1) The quality of information in online marketing channels that are effective in providing information such as communication, content and 
completeness, found that $39 \%$ of Facebook followed, 33\% of online order form, next to Line $12 \%$, Instagram and Shopee 10 percent and 6 percent, respectively. 2) The quality of the system of use of online marketing channels found that the results of the experiment are sold through online marketing channels, when comparing the best performance results as follows; Facebook is the most accessible channel for customers at 78.23 percent, followed by Instagram at 10.39 percent, Shopee at 6.76 percent, Line and online order form at $3.11 \%$ and $1.51 \%$ respectively. The most revenue-generating online marketing channel was Facebook at 68.15 percent, followed by order from online at 15.66 percent, followed by Instagram at 10.32 percent and Line at 5.98 percent. The most repurchases were online order form at 60 percent, followed by Line at 16 percent, followed by Instagram at 14 percent and Facebook at 10 percent. The most user-friendly online marketing channel was Facebook at $72 \%$, followed by Line at $20 \%$, Instagram at $3 \%$, online order form at $3 \%$ and Shopee at $2 \%$. The highest sales effectiveness of online marketing channels, such as interactions, product presentations, and closing sales was Facebook at 45 percent, followed by online order form at 35 percent, followed by Line at 10 percent, Instagram at 7 percent and Shopee at 3 percent. The costs of selling through online marketing channels such as time for sale, administrative expenses, internet expenses, advertising expenses, there is a similar proportion of expenses. The highest was Facebook, Shopee, Line, Instagram and online order form at 26, 25,23,15,11 percent respectively. 3) Online marketing channels that affect individuals found that Facebook was at 66 percent, followed by Line at 14 percent, followed by Instagram at 8 percent, Shopee 4 at percent, and online order from at 2 percent. The detail can be show from Figure 10-17

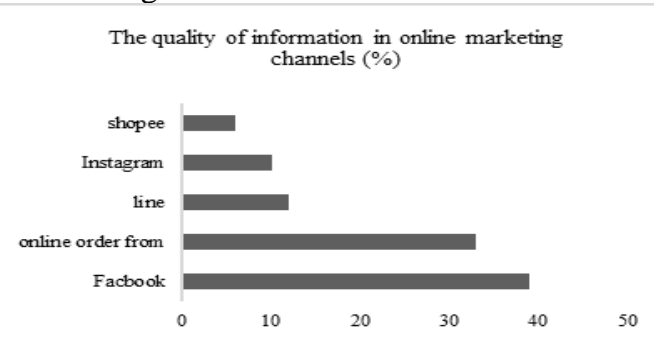

Figure 10 The quality of information in online marketing channels.

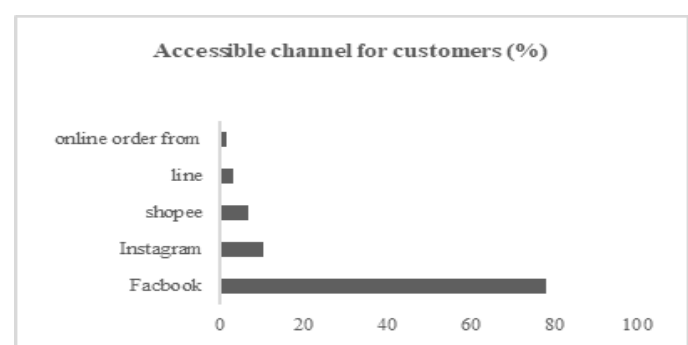

Figure 11 The quality of the system of use of online marketing channels results accessible channel for customers.

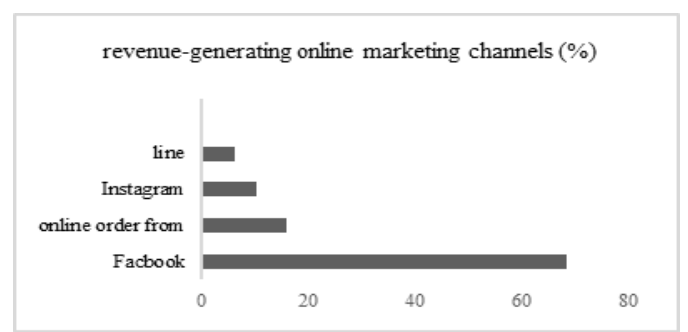

Figure 12 revenue-generating online marketing channels.

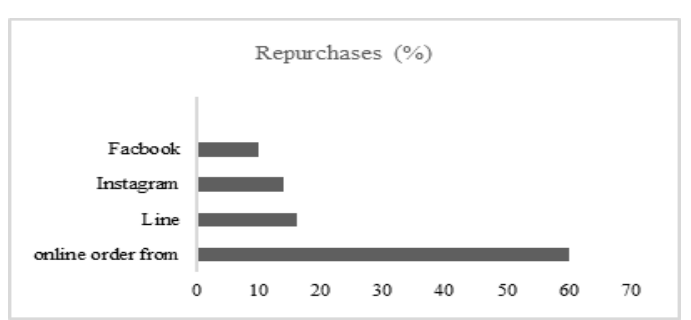

Figure 13 repurchases were online marketing channels.

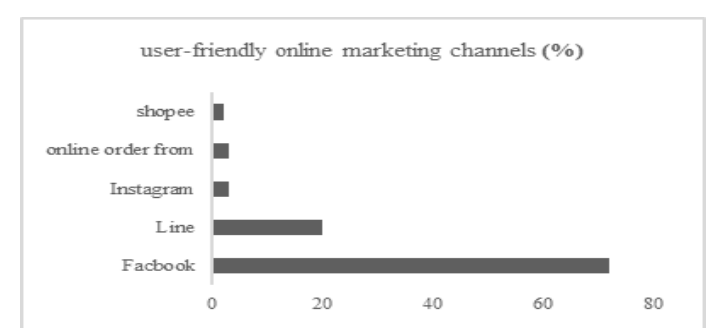

Figure 14 user-friendly online marketing channels.

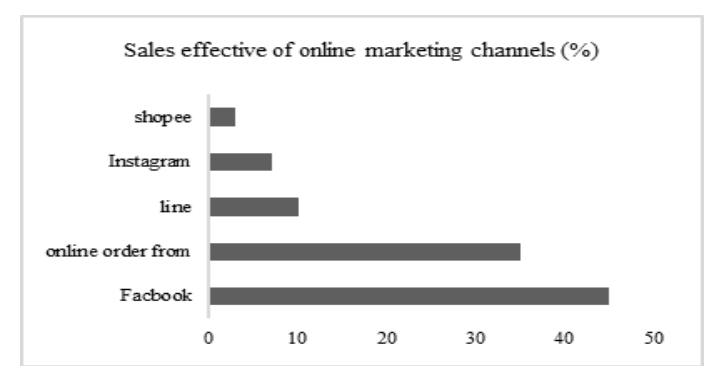

Figure 15 Sales effectiveness of online marketing channels.

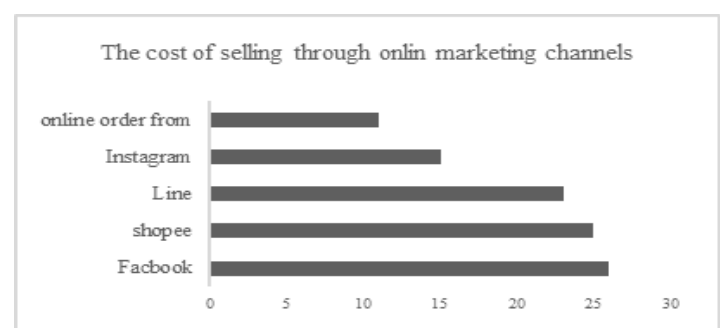

Figure 16 The cost of selling through online marketing channels.

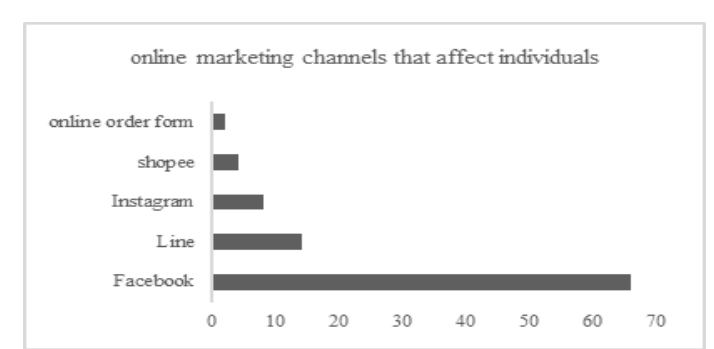

Figure 17 online marketing channels that affect individuals. 
Therefore, from the sales trial results, comparing the performance between Facebook, Instagram, Line, online order form and Shopee, it was found that Facebook has higher sales revenue than other online marketing channels. Because Facebook is an easily accessible marketing channel. The number of customers is greater than accessibility, sharing, inquiries, ordering. In addition, it provides the convenience of updating information and the farmer is very familiar with its use. The weakness of the Facebook channel is the invisible users, resulting in less product information or promotions posted to customers, including the relatively high ad rates. While, the online marketing channel on Instagram is suitable for customers in cities, health-conscious people with high purchasing power. The presentation should focus on taking beautiful pictures that attract attention. Providing additional information, rather than selling products, creates a positive image, generating positive feedback from customers, and in this channel there are no visibility blocking and high ad rates issues. However, there are restrictions on the use of Instagram, there is still a specific use of the group. However, there are restrictions on the use of Instagram, there is still a specific use of the group. Online marketing channels through Line have a specific style of communication with individual customers. It has a personal marketing style. Line marketing is often used in conjunction with Facebook or Instagram. In the case of using most of the LINE channels, they will trade with each other and build trust, resulting in repurchases. Online marketing channels through order form online are the same as Line, but there is a difference in the resolution of providing product information. Also able to collect information to process the trading systematically. Because it uses the Google form function to make orders that can be sent directly to the customer for use in conjunction with other online channels as well. This method maximizes repurchases. It can be managed by itself and can be kept confidential. This system can support financial transactions with high security. Lastly, selling through the Market Place platform on Shopee, is the only platform that allows vegetables to be sold through online marketing channels, which are unsuccessful channels for sales. Due to the limitation of the short-lived product (vegetables). Making it necessary to be careful in transportation. Selling through this channel, buyers are skeptical of sellers as they are difficult to verify their identity and are more difficult to process because of trading and financial activities. This is in line with the study of the Thai e-Commerce Association (2018), which discusses the benefits of online marketing as a high potential channel for doing business. It can trade 24 hours a day, sell products all over the world, stay up to date, two-way communication, low operating costs. Also technology helps to make the product presentation attractive. It helps consumers to make purchasing decisions quickly. The key issue in creating an online marketing system for safe vegetable farmers must be participation. Since the requirement identification process and the design process, stakeholders in the safety vegetable industry must share their opinions and provide feedback when it comes to form an online marketing channel for safe vegetable. It is then tested with the consumers about the behaviour and the satisfaction of using it for improvement by application in conjunction with the Extended Model of Internet Commerce
Adoption (eMICA). This includes quality inputs and completeness of information, processes, system quality to create farmers who can use online marketing channels and achieve the SMART Farmers Model. Productivity is a quality online marketing channel. Serving customer needs and generating repurchases. All of the elements above represent an effective form of online marketing for safe vegetable in Thailand.

\section{Conclusion}

This study helps to expand the scope of the development of new online marketing channels. This is due to the driving of the objective of developing potential, the ability to apply technology to increase the market for farmers in Thailand. However, there is a low limit on repurchase due to the relatively high number of competitors on Facebook channels. Including problems caused by blocking visibility and high ad rates. The online marketing channel suitable for customers in cities with high purchasing power is Instagram. The presentation style should focus on beautiful images, compelling content. The online marketing channels that should be used together to create the most effective sales are Facebook, Line and order form online, as this will combine the strengths of each tool. Facebook will focus on communicating and distributing information in a wide area. When customers receive information and they are interested, they will use private channels such as Messenger and Line to contact us for details, which will lead to purchasing decisions. The ideal way to repurchase is order form online, which adds convenience, systematic functionality and easy monitoring. Findings from the research that shipping, packaging, and consumer behaviour are emerging factors in the process of developing online marketing channels. This is because online merchandising relies on efficient shipping and distribution processes. Packaging that maintains the quality of vegetable through a logistics process that will reach the end consumer. In conjunction with the study of consumer behaviour in online marketing channels using the concept of online marketing mix $6 \mathrm{P}+2 \mathrm{C}+3 \mathrm{~S}$ to develop an online marketing channel model, and combine with enhancing the potential of farmers using the SMART FARMERS model. These include social media or market place, marketing tools, assistant, product distribution, digital technology. This research found 5 strategies for selling through online marketing channels; 1) Beautiful pictures and complete information such as price, type of vegetables, weight, cultivation area, producer. 2) Reviewing and recommending each vegetable creates more interest to customers who want to consume more vegetables. 3) Establishing consistency in posting information in online marketing channels. Data should be updated 1-2 times a week to create a follow-up for customers. 4) Story creation in content presented on online platform (content marketing) such as knowledge of safe vegetables in the local area, simple method of growing safe vegetable. 5) Create participation in promotional activities such as accumulating points, applying for membership, receiving privileges. Summarise the main findings of this study, confirm the hypothesis that many farmers or entrepreneurs in Thailand do not take online marketing channels seriously and maximize their benefits. The results of this study understand 
the fundamental changes in customer behaviour and online marketing activities that are suitable for which target audience and what types of products. Including digital transformation trends that are important to online performance (Simmons, et al., 2007). Future research approach is to expand the scope of studies testing online marketing channels to other agricultural products. As for the online marketing model, it is a future proactive marketing model that is rapidly changing through traditional trading. Everyone must keep pace with the change to gain a competitive advantage. Also more accurate target reach, interact directly with customers and receive real-time feedback to get accurate answers, be the best to meet the needs of customers. Effective marketing is always a key component of any business success.

\section{References}

[1] Ary, Donald et al. (2003). Introduction to Research in Education. USA: CBS College Publishing.

[2] Audrey Gilmore, Michele o'dwyer and David Carson. (2009). Innovative marketing in SMEs. European Journal of Marketing. 43 (1/2) : 46-61.

[3] Burgess, L., Cooper, J. \& Alcock, C. (2001). The adoption of the Web as a marketing tool by Reginal Tourism Associations (RTAs) in Australia. ACIS2001 Proceedings. Retrieved June 20, 2012, from: http://aisel.aisnet.org/acis2001/9

[4] Chen, J., \& McQueen, R. J. (2008). Factors affecting e-commerce stages of growth in small Chinese firms in New Zealand: An analysis of adoption motivators \& inhibitors. Journal of Global Information Management, 16(1), 26-60.

[5] Donald, J., \& David, J. (1996). The Integrated Supply Chain Process. New York: McGraw-Hill Companies.

[6] Dooline, B., Burgess, L., \& Cooper, J. (2002). Evaluating the use of the web for tourism marketing: a case study from New Zealand. Tourism Management, 23, 557561.

[7] Hernández, B., Jimenez, J., \& Martin, J. (2010). Customer behavior in electronic commerce: The moderating effect of epurchasing experience. Journal of Business Research, 63(9-10), 964-971.
[8] Huei Huang Kuan, Gee Wood Bock and Vichita Vathanophas. (2008).Comparing the effects of website quality on customer initial purchase and continued purchase at e-commerce websites. Behaviour and Information Technology. 27(1): 3-16

[9] Julian Terry and Craig Standing. (2001). User Involvement in E-Commerce Systems Development. ACIS 2001 PROCEEDINGS. 64.

[10] Kirthi Kalyanam and Shelby H. Mcintyre. (2002). The E-Marketing Mix: A Contribution of the E-Tailing Wars. Journal of the Academy of Marketing Science. 30(4):487-499.

[11] Li, Y., Hu, C. Huang, C. \& Duan, L. (2017). The concept of smart tourism in the context of tourism information services. Tourism Management, 58, 203300.

[12] Laudon, K. C., \& Laudon, J. P. (2016). Technology rent vs. buy decision. Management information systems: Managing the digital firm.

[13] National Statistical Office. (2019). Important Results Survey on the State of E-Commerce of Thailand 2011. Retrieved March 15, 2014. fromhttp://service.nso.go.th/nso/nsopublis h/themes/files/electThaiRep54. pdf

[14] Office of the Permanent Secretary, Ministry of Commerce (2017). Statistics of agricultural export data of Thailand. Retrieved on 20 March, 2017,from http://www.moc.go.th/index.php/flowerservice-all-6/category/categoryproduct004-copy-3-copy-copy.html

[15] Office of Provincial Agriculture Nakhon Pathom. (2016). Agricultural product data statistics, Nakhon Pathom Province. Retrieved 20 March, 2017, from http://www.nakhonpathom.doae.go.th/

[16] Office of the National Economic and Social Development Council.(2019).Gross Domestic Product.

[17] Statistics.https://www.nesdc.go.th/ewt_w3 c/more_news.php?filename $=q g d p \_p a g e \& c$ $\mathrm{id}=75$ 
[18] Office of the National Economic and Social Development Board; NESDB. (2019). Agriculture Export from Thailand. https://www.nesdc.go.th/nesdb_en/main.p hp?filename=national_account

[19] Paul Timmers. (1999). Electronic Commerce. John Wiley \& Sons, Inc.605 Third Ave. New York, NY United States. 288

[20] Philip Kotler and Gary Armstrong.(2001). Principles of Marketing, 9th ed. Upper Saddle River, NJ: Prentice Hall. p. 403.

[21] Simmons, M.J., Ryzek, D.F., Lamour, C., Goodman, J.W., Kummer, N.E., Merriman, P.J. (2007). Cytotype regulation by telomeric $\mathrm{P}$ elements in Drosophila melanogaster: Evidence for involvement of an RNA interference gene. Genetics 176(4): 1945--1955.

[22] Thompson S.H. Teo \& Pian. (2003). A contingency perspective on Internet adoption and competitive advantage. European Journal of Information System. $12(2): 78-92$.

[23] William Delone \& Ephraim McLean. (2003).The DeLone and McLean Model of Information Systems Success: A Ten-Year Update. Journal of Management Information Systems. 19(4) :9-30

[24] Xiuhui \& Qinan. (2007). Coordination mechanisms of supply chain systems. European Journal of operational Research 179 (1) : 1-16 